\title{
Hague Case Law: Latest Developments
}

\section{Anna Meijknecht ${ }^{1}$}

Published online: 21 March 2019

(c) The Author(s) 2019

\section{International Court of Justice}

(1) Legal Consequences of the Separation of the Chagos Archipelago from Mauritius in 1965 (Advisory Opinion)

On 25 February 2019 the International Court of Justice (ICJ) gave its Advisory Opinion on the Legal Consequences of the Separation of the Chagos Archipelago from Mauritius in 1965.

In resolution 71/292 adopted on 22 June 2017 by the General Assembly the following questions were submitted to the Court: (a) Whether the process of decolonization of Mauritius was lawfully completed having regard to international law and (b) what the consequences are under international law arising from the continued administration by the United Kingdom of the Chagos Archipelago.

The Court, after establishing that it has jurisdiction to give the advisory opinion requested, recalled the circumstances of the case: On 23 September 1965, the Government of the United Kingdom and the representatives of the colony of Mauritius concluded the Lancaster House Agreement, by virtue of which the representatives of Mauritius agreed in principle to the detachment of the Chagos Archipelago in exchange for, among other things, a sum of $£ 3$ million. On 8 November 1965 , the United Kingdom established a new colony known as the British Indian Ocean Territory ('BIOT') consisting inter alia of the Chagos Archipelago, which was detached from Mauritius. In 1966, an agreement was concluded between the United States and the United Kingdom for the establishment of a military base by the United States on the Chagos Archipelago. Between 1967 and 1973, the inhabitants of the Chagos Archipelago who had left the islands were prevented from returning. The other inhabitants were forcibly removed and prevented from returning. To date, the Chagossians remain dispersed in several countries, including the United Kingdom, Mauritius and the Seychelles and are not allowed to return to the Chagos Archipelago by virtue of United Kingdom law.

Anna Meijknecht

a.k.meijknecht@asser.nl

1 Tilburg Law School, Tilburg, The Netherlands 
In the Court's view the law on self-determination constitutes the applicable international law during the period between the separation of the Chagos Archipelago from its territory in 1965 and its independence in 1968. The Court in particular recalled that the peoples of non-self-governing territories are entitled to exercise their right to self-determination in relation to their territory as a whole and that any detachment by the administering Power of part of a non-self-governing territory, unless based on the freely expressed and genuine will of the people of the territory concerned, is contrary to the right to self-determination.

After recalling the circumstances in which the colony of Mauritius agreed in principle to such a detachment, the Court considered that this detachment was not based on the free and genuine expression of the will of the people concerned. It took the view that the obligations arising under international law and reflected in several resolutions adopted by the General Assembly during the process of decolonization of Mauritius require the United Kingdom, as the administering Power, to respect the territorial integrity of that country, including the Chagos Archipelago. The Court concluded that, as a result of the Chagos Archipelago's unlawful detachment and its incorporation into a new colony, known as the BIOT, the process of decolonization of Mauritius was not lawfully completed when Mauritius acceded to independence in 1968.

Subsequently, the Court examined the consequences, under international law, arising from the United Kingdom's continued administration of the Chagos Archipelago. In the Court's opinion this continued administration constitutes a wrongful act entailing the international responsibility of the State. The Court concluded that the United Kingdom has an obligation to bring to an end its administration of the Chagos Archipelago as rapidly as possible and that all Member States are under an obligation to co-operate with the United Nations to complete the decolonization of Mauritius. Since respect for the right to self-determination is an obligation erga omnes all States have a legal interest in protecting that right.

\section{(2) Bolivia v. Chile (Judgment)}

On 1 October 2018, the ICJ delivered its Judgment in the case between Bolivia and Chile concerning the Obligation to Negotiate Access to the Pacific Ocean. In this case Bolivia has requested the Court to adjudge and declare that 'Chile has the obligation to negotiate with Bolivia in order to reach an agreement granting Bolivia a fully sovereign access to the Pacific Ocean'.

In its Judgment of 24 September 2015 on the preliminary objection raised by Chile, the Court already explained, as a more general point, that while States are free to resort to negotiations or put an end to them, they may agree to be bound by an obligation to negotiate. In that case, States are required under international law to enter into negotiations and to pursue them in good faith. In its present Judgment the Court analyzed the various legal bases put forward by Bolivia to support its claim that Chile has an obligation to negotiate Bolivia's sovereign access to the Pacific Ocean.

The Court first examined Bolivia's claim resting on the alleged existence of one or more bilateral agreements that would impose on Chile an obligation to negotiate 
Bolivia's sovereign access to the sea, and concluded that none of the instruments invoked by Bolivia establishes such an obligation on Chile. Likewise, declarations and other unilateral acts invoked by Bolivia and containing formulations such as: Chile declared that it was 'willing to seek that Bolivia acquire its own outlet to the sea' and 'to give an ear to any Bolivian proposal aimed at solving its landlocked condition', according to the Court, do not suggest that Chile has undertaken a legal obligation.

The Court then noted that neither 'Acquiescence', nor 'Estoppel', nor 'Legitimate expectations' can provide a legal basis for Chile's obligation to negotiate Bolivia's sovereign access to the sea.

The Court further examined Article 2, paragraph 3, of the United Nations Charter and Article 3(i) of the OAS Charter, but concluded that no obligation to negotiate Bolivia's sovereign access to the sea arises for Chile under those two Charters.

The Court next considered Bolivia's argument that 11 resolutions of the OAS General Assembly which dealt with the issue of Bolivia's sovereign access to the Pacific Ocean confirm Chile's commitment to negotiate that issue, but noted that these resolutions merely recommend to Bolivia and Chile that they enter into negotiations over the issue, and, moreover, that resolutions of the General Assembly of the OAS are not per se binding and cannot be the source of an international obligation.

Finally, the Court examined Bolivia's argument that, even if there is no instrument, act or conduct which, taken individually, creates an obligation to negotiate its sovereign access to the sea, all these elements may cumulatively have a 'decisive effect' for the existence of such an obligation. The Court pointed out that, given that its analysis shows that no obligation to negotiate Bolivia's sovereign access to the Pacific Ocean has arisen for Chile from any of the invoked legal bases taken individually, a cumulative consideration of the various bases cannot add to the overall result.

After observing that 'Bolivia and Chile have a long history of dialogue, exchanges and negotiations aimed at identifying an appropriate solution to the landlocked situation of Bolivia following the War of the Pacific and the 1904 Peace Treaty' the Court stated that it is unable on the basis of the material submitted to it to conclude that Chile has the obligation to negotiate with Bolivia in order to reach an agreement granting Bolivia a fully sovereign access to the Pacific Ocean. The Court added that its finding should not be understood as precluding the Parties from continuing their dialogue and exchanges, in a spirit of good neighbourliness, to address the issues relating to the landlocked situation of Bolivia, the solution to which they have both recognized to be a matter of mutual interest.

(3) Alleged Violations of the 1955 Treaty of Amity, Economic Relations, and Consular Rights (Islamic Republic of Iran v. United States of America) (Provisional Measures)

On 16 July 2018, Iran instituted proceedings against the United States with regard to alleged violations of the 1955 Treaty of Amity, Economic Relations, and Consular Rights (Islamic Republic of Iran v. United States of America) and, on the same day, submitted a Request for the indication of provisional measures, seeking to preserve its rights under the 1955 Treaty pending the Court's final decision in the case. On 3 
October 2018, the ICJ delivered its Order on the Request for the indication of provisional measures submitted by Iran.

On 8 May 2018, the President of the United States issued a National Security Presidential Memorandum announcing the end of the participation of the United States in the Joint Comprehensive Plan of Action (JCPOA) ${ }^{1}$ and directing the reimposition on Iran of 'sanctions lifted or waived in connection with the JCPOA'. It was announced that 'sanctions' would be reimposed in two steps. Upon the expiry of a first wind-down period of 90 days, the United States would reimpose a certain number of 'sanctions' concerning, in particular, financial transactions, trade in metals, the importation of Iranian-origin carpets and foodstuffs, and the export of commercial passenger aircraft and related parts. Following a second wind-down period of 180 days the United States would reimpose additional 'sanctions'.

The Court concluded it has jurisdiction pursuant to Article XXI, paragraph 2, of the 1955 Treaty to deal with the case. It then established that the rights that Iran is claiming, and for which it is seeking protection, are plausible in so far as they relate to the importation and purchase of goods required for humanitarian needs as well as goods and services required for the safety of civil aviation. After specifying the link between the provisional measures requested and the rights asserted by Iran, the Court stated that those rights are of such a nature that disregarding them may entail irreparable consequences. In its opinion, the measures adopted by the United States have the potential to endanger civil aviation safety in Iran and the lives of its users to the extent that they prevent Iranian airlines from acquiring spare parts and other necessary equipment, as well as from accessing associated services necessary for civil aircraft. The Court further considered that restrictions on the importation and purchase of goods required for humanitarian needs, such as foodstuffs, medicines, and medical equipment may have a serious detrimental impact on the health and lives of individuals on the territory of Iran.

The Court concluded that the conditions required to indicate provisional measures are met and indicated that the United States must remove any impediments arising from the measures announced on 8 May 2018 to the free exportation to the territory of Iran of, inter alia, medicines and medical devices, foodstuffs, and spare parts and equipment necessary for the safety of civil aviation. It also ordered that both Parties must refrain from any action which might aggravate or extend the dispute before the Court or make it more difficult to resolve.

Open Access This article is distributed under the terms of the Creative Commons Attribution 4.0 International License (http://creativecommons.org/licenses/by/4.0/), which permits unrestricted use, distribution, and reproduction in any medium, provided you give appropriate credit to the original author(s) and the source, provide a link to the Creative Commons license, and indicate if changes were made.

Publisher's Note Springer Nature remains neutral with regard to jurisdictional claims in published maps and institutional affiliations.

\footnotetext{
1 The Joint Comprehensive Plan of Action (JCPOA) is an agreement on the nuclear programme of Iran reached on 14 July 2015 by Iran, the five permanent members of the United Nations Security Council, plus Germany and the European Union.
} 